\title{
Algunas consideraciones acerca de la presencia de Homero en la obra de Unamuno
}

\author{
José Ramón DEL CANTO Nieto \\ IES Madina Mayurqa (Palma de Mallorca) \\ josdelcanto@yahoo.es
}

Recibido: 12-05-2015

Aceptado: 28-09-2015

\section{RESUMEN}

Miguel de Unamuno fue un constante lector de poesía épica, en la que Homero siempre tuvo un lugar preferente, y no solo por motivos profesionales. A lo largo de su obra, tanto en prosa como en verso, pueden rastrearse distintas y a veces contradictorias referencias a la Ilíada y la Odisea sobre las que hizo profundas reflexiones, intentando siempre ajustarlas a su propia visión de la vida y de la muerte. Desde esta perspectiva se acerca a escenarios como el 'prado de asfódelos', o, a partir del símil homérico, al 'sucederse de las generaciones de las hojas y de los hombres', o a figuras míticas como las Sirenas, Helena, Tántalo, Sísifo y Ulises.

Palabras clave: Homero, Épica, Prado de Asfódelos, Generaciones, Sirenas, Helena, Tántalo, Sísifo, Ulises.

\begin{abstract}
Miguel de Unamuno was a constant reader of epic poetry, in which Homer always occupied a special place, not only for professional reasons. Throughout his work, both in prose and verse, it is possible to trace different and sometimes contradictory references to the Iliad and the Odyssey, about which he made profound reflections, and which he tried to adjust to his own view of life and death. From this perspective he approached images as the 'asphodel meadow' or, based in the Homeric simile, the 'succession of generations of leaves and men', or mythical figures like the Sirens, Helen, Tantalus, Sisyphus and Ulysses.
\end{abstract}

Keywords: Homer, Epic, asphodel meadow, generations, Sirens, Helen, Tantalus, Sisyphus, Ulysses.

La relación más antigua de Unamuno con Homero está asociada, como en Machado, a la infancia. De manera parecida a D. Antonio, que en unos versos de Campos de Castilla exclama con nostalgia:

$¡ A h$, cuando yo era niño soñaba con los héroes de la Ilíada!

Ayax era más fuerte que Diómedes,

Héctor, más fuerte que Ayax, 
y Aquiles el más fuerte; porque era

el más fuerte...¡inocencias de la infancia!... ${ }^{1}$

al rememorar los juegos de la infancia en sus Recuerdos de niñez y mocedad, hace la siguiente evocación D. Miguel:

Solemnes y casi religiosas — si la religión se redujera, como muchos piensan, al rito- eran las fórmulas de que nos servíamos para nuestros tratos y contratos, trueques y cambalaches; en ellas, como en las suyas los antiguos pueblos, hacíamos a nuestros dioses testigos de nuestra fidelidad, y cada vez que en Homero leo cómo los héroes aqueos o troyanos invocaban a los dioses poniéndolos por testigos de su palabra, y conminaban con la ira divina a los perjuros, recuerdo nuestras fórmulas infantiles ${ }^{2}$.

Unamuno siempre amó el carácter tradicional de la poesía oral, la que destila la técnica sagrada de los poetas del pueblo y que llega, como en los tiempos homéricos por boca de los recitadores ciegos, hasta sus días ${ }^{3}$. En su novela Paz en la guerra dice de su personaje Ignacio, que habla por boca del propio Unamuno, las siguientes palabras:

Hacía una temporada que le había dado a Ignacio con ardor por comprar en la plaza del mercado al ciego que los vendía, aquellos pliegos de lectura, que sujetos con cañitas a unas cuerdas, se ofrecían al curioso; pliegos sueltos de cordel. Era la afición de moda entre los chicos, que los compraban y se los trocaban. Aquellos pliegos encerraban la flor de la fantasía y de la historia; los había de historia sagrada, de cuentos orientales, de epopeyas medievales del ciclo carolingio, de libros de caballerías, de las más celebradas ficciones de la literatura europea, de la crema de la leyenda patria, de hazañas de bandidos y de la guerra civil de los siete años. Eran el sedimento poético de los siglos, que después de haber nutrido los cantos y relatos que han consolado de la vida a tantas generaciones, rodando de boca en oído y de oído en boca, contados al amor de la lumbre, viven, por ministerio de los ciegos callejeros, en fantasía, siempre verde, del pueblo ${ }^{4}$.

Cuando alaba la frescura de la tradición oral, considera a la homérica «sublime». No alberga dudas de que los poemas homéricos son una parte esencial y originaria de la más auténtica tradición de la humanidad, aquella que se aprende y enseña antes de que se sepa leer y escribir, porque, al igual que ocurre con las canciones de los corros infantiles, pertenece más que a la Literatura (y no digamos a la Filología), a la Poesía pura,

${ }^{1}$ Machado, Proverbios y cantares CXXXVI, XVIII. OC., II, p. 572.

${ }^{2}$ RNM, OC., VIII, p. 121.

${ }^{3}$ Sobre la relación entre pueblo y autor hay una anécdota curiosa: Unamuno firmó un prólogo a una obra de Luis Maldonado en el que alababa el carácter poético popular de las composiciones recitadas por los ciegos. Al revelarle éste que el autor era él mismo, Unamuno escribió su «Romance a Luis Maldonado por sus querellas del ciego de Robliza», en que se reafirma en su opinión, matizando que en toda poesía popular ha de haber un autor culto que refleje el espíritu del pueblo. Cf. PC., IV, pp. 21-24.

${ }^{4} P G$, OC., II, pp. 106-107. 
representan la verdadera tradición, la fundamental, la anterior al arte de la escritura, esa tradición que el documento nos impide comprender y sentir. Y esa tradición primitiva e infantil, clásica, se transmite más fielmente que la escrita. Cambian más los escritos al pasar de copista a copista o de escritor a escritor que los relatos orales al pasar de boca en boca. No hay copistas que no la corrompan ni cristalicen. Los poemas homéricos ¿no empezaron a estropearse así que por la escritura fueron fijados? ${ }^{5}$

Los poemas homéricos están en Unamuno asociados sin duda a la infancia, y también a la tradición «primitiva e infantil» de la humanidad. En este sentido se revelan como su aurora, y en su repetición temporal hacen revivir, una vez y otra, la eterna sensación alegre de aquello que siempre comienza de nuevo ${ }^{6}$. Con esta imagen presente, Unamuno escribió en su Cancionero un poema ${ }^{7}$ encabezado por la fórmula

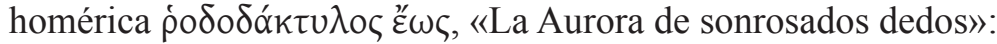

Cuando el dedo de rosa de la Aurora

abrió el libro del día,

página en blanco de alba, la hora,

leímos alegría;

Y cuando hace balance de los años que vivió en su Bilbao natal antes de marchar a estudiar a la Universidad de Madrid, al aquilatar el valor de la infancia, escribe estas palabras en el bello colofón con que da término a sus Recuerdos de niñez y mocedad:

Nuestros primeros años tiñen con la luz de sus olvidados recuerdos toda nuestra vida, recuerdos que aun olvidados siguen verificándonos desde los soterraños de nuestro espíritu, como el sol que sumergido en las aguas del océano las ilumina por reflejo del cielo ${ }^{8}$.

Pues bien, de la misma manera que la infancia es época en que la claridad ilumina el alma de cada uno hasta acabar tiñendo de por vida los recuerdos con su luz, de manera parecida se complace D. Miguel en reafirmar:

Son grandes los poemas homéricos, porque de sus inmortales páginas transpira vivificadora brisa de la infancia de nuestra civilización ${ }^{9}$

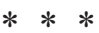

${ }^{5}$ RNM, OC.,VIII, p. 115.

${ }^{6}$ Esta idea está presente en el «Otro poema de los dones» de J.L. Borges: «Por la mañana, que nos depara la ilusión de un principio» (en El otro, el mismo, 1964, OC., II, pp. 314-315). Dice también Unamuno, haciendo hincapié en su contradicción: «Para los que sienten la agitación, nada es nuevo bajo el sol, y éste es estúpido en la monotonía de los días; para los que viven en la quietud, cada nueva mañana trae una frescura nueva». ETC, OC. I, p. 792.

${ }^{7}$ Con fecha 26 de marzo de 1929, n. ${ }^{\circ}$ 955.; OP., III, p. 463. Cita también unos versos del Corán (LXXXI-10,11) con los que forma una especie de dístico.

${ }^{8} R N M$, OC., VIII, p. 154.

${ }^{9} R N M$, OC., VIII, p. 155. 
Una atenta lectura de Paz en la guerra, su primera novela, situada en el querido Bilbao de su infancia en el escenario de las Guerras Carlistas revela (en palabras de Jon Juaristi ${ }^{10}$ ) un "cañamazo mítico» análogo al del Ulysses de Joyce, dando por supuesto que es la Ilíada la que proporciona los principales arquetipos de referencia de su infancia: La obra evoca - dice - «el cerco de Troya y la muerte de los jóvenes héroes ante sus murallas, trasladados por Unamuno al sitio de Bilbao de 1873-1874» ${ }^{11}$. Pero la lectura de Homero seguirá acompañando también a D. Miguel en momentos de sosiego. Una vez y otra evocará, como veremos, el lugar junto al fuego donde se cuentan los relatos que han consolado a tantas generaciones de hombres. Al amor de la lumbre es, precisamente, el título del soneto que transcribimos más abajo en el que recrea el símil homérico de las generaciones humanas que se suceden:

Como la generación de las hojas, así también la de los hombres unas el viento las esparce por tierra, a otras las hace brotar el floreciente bosque, cuando llega la primavera; así la generación de los hombres, una brota y otra termina ${ }^{12}$.

Pero ya en su primer libro lírico, titulado Poesías, en el poema El mar de encinas ${ }^{13}$, al hablar de la firmeza de estos árboles, que simbólicamente siempre fueron para él como la imagen de la eternidad inmóvil ${ }^{14}$, decía:

Como los días, van sus recias hojas

rodando una tras otra al pudridero

y siempre verde el mar, de lo divino

nos es espejo.

Pocos años después, en su Rosario de sonetos líricos, encontramos el poema que viene encabezado por unas palabras de San Agustín, aquellas en las que evoca en sus Confesiones al Dulcissime vanus Homerus:

$\mathrm{Al}$ amor de la lumbre cuya llama como una cresta de la mar ondea se oye fuera la lluvia que gotea

sobre los chopos. Previsora el ama

${ }^{10}$ Juaristi (2012: 247). Previamente, en el capítulo II (pp. 43-54) el autor señala la confusión entre recuerdos vividos y lecturas, algo que, sin embargo, no cambia ni interfiere en la concepción que de la épica tiene Unamuno.

${ }^{11}$ Juaristi (2012: 247). Ramón Buckey definió la novela como «Romance épico» (citado por Juaristi en este mismo lugar).

${ }^{12}$ Il. VI, pp. 146-149. Tad. J.M. Pabón.

${ }^{13}$ Fechado en Salamanca, el 13 de septiembre de 1906, OP., I, pp. 62-63.

${ }^{14}$ Así puede apreciarse en el poema «La encina y el sauce», fechado en Salamanca el 4 de octubre de 1910, en RSL, LVI: «La inmoble encina al cielo inmoble alza redonda/ la copa prieta que ni cierzo frío riza/ mientras el sauce llorón en el agua huidiza / la cabellera tiende hendiéndola en la onda» (OP., I, p. 293). 
supo ordenar se me temple la cama con sahumerio. En tanto la Odisea montes y valles de mi pecho orea de sus ficciones con la rica trama

preparándome al sueño. Del castaño que más de cien generaciones de hoja criara y vio morir cabe el escaño

abrasándome el tronco con su roja brasa me reconforta. ¡Dulce engaño la ballesta de mi inquietud afloja! $!^{15}$

Es ahora, como puede verse, el tizón del castaño consumiéndose en brasas (el «sedimento poético de los siglos») el firme testigo del ardiente e incesante sucederse de las generaciones humanas, idea que ya había expresado un par de años antes en otro poema $^{16}$, esta vez en la imagen de un niño que cifra generaciones enteras:

Mira ese niño;

¡cuántos siglos sobre él...generaciones!

$\mathrm{Su}$ cabecita rubia

sostiene el peso

de vidas por millones.

¡Qué antiguo es ese niño!

¡Cuántos han muerto para que él naciera!

¡En él cuaja la historia;

en él acaban tantas largas guerras!...

El es la gloria

de esa incontable muchedumbre oscura

de vidas enterradas;

¡ es la flor de la selva!

Encarna, sin saberlo,

Ramayanas, Ilíadas, Odiseas,

Pentateucos, Eneidas, Kalevalas

invasiones de pueblos,

Cruzadas y además revoluciones.

Toda la humanidad de que brotara

en esa cabecita se condensa;

estás ante el misterio.

Mira ese niño:

¡él es el evangelio! ${ }^{17}$.

${ }^{15}$ RSL, CVI, Salamanca, 27 de noviembre, 1910 (OP., I, p. 326).

${ }^{16}$ Mira ese niño, fechado en 1908. PS. (OP., IV, p. 86).

${ }^{17}$ Este poema puede compararse con estos versos de Ángel Gonzalez: «Para que yo me llame Ángel González, / para que mi ser pese sobre el suelo/ fue necesario un ancho espacio/ y un largo tiempo:/ hombres de todo mar y toda tierra,/ fértiles vientres de mujer, y cuerpos/ y más cuerpos fundiéndose in- 
También Machado, como ha visto certeramente el profesor Ignacio Rodriguez Alfageme ${ }^{18}$, elaboró poéticamente el pasaje de Homero que compara las hojas de los árboles que se suceden conforme a las estaciones con las generaciones de los hombres con estos versos:
Las hojas de un verde mustio, casi negras, de la acacia, el viento de septiembre besa, y se lleva algunas amarillas, secas, jugando entre el polvo blanco de la tierra ${ }^{19}$.

Y, de manera explícita, trató D. Antonio este tema bajo la figura de Juan de Mairena, personaje en quien desdobla su yo, cuando al aleccionar a sus discípulos les dice:

Sobre la muerte, señores, hemos de hablar poco. Sois demasiado jóvenes... Sin embargo no estará de más que comencéis a reparar en ella como fenómeno frecuente y, al parecer natural, y que recitéis de memoria el hexámetro de Homero:

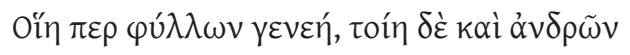

... Homero habla aquí de la muerte como un gran épico que la ve desde fuera del gran bosque humano. Pensad en que cada uno de vosotros, la verá un día desde dentro, y coincidiendo con una de esas hojas ${ }^{20} \ldots$

Esta última será, en efecto, la actitud de Unamuno - y manifestación de su sentimiento trágico- - pues hasta el final de su vida quiso vivir su muerte desde dentro ${ }^{21}$, acompañada de un hondo deseo de inmortalidad consciente y personal, no como un fenómeno externo que tan sólo atañera a la Vida —Zoń — y a la Humanidad de manera abstracta y general, sino como una hoja consciente - ßíos - de la temporalidad del gran Árbol de la Vida.

$$
* * *
$$

La huella de Homero se deja sentir en toda la obra unamuniana, tanto en prosa como en verso, a veces de manera muy explícita, como en los lemas que, a modo de

\footnotetext{
cesantes/ en otro cuerpo nuevo....En Áspero mundo, 1956. De modo parecido Borges, en su poema «Las causas» (Historia de la noche OC., III, p. 199), tras una larga enumeración (Los ponientes, las generaciones, los días, etc.) concluye: «Se precisaron todas esas cosas / para que nuestras manos se encontraran».

${ }^{18}$ Rodríguez Alfageme (2010).

${ }^{19}$ Soledades XIX, OC. II, pp. 442-443.

${ }^{20}$ Juan de Mairena, OC. IV, p. 1956.

${ }^{21}$ Hasta el punto de desear «morir con los ojos abiertos». Cf. RD VII, Hendaya, 24 de diciembre de 1925 (OP. II, pp. 377-378).
} 
exerga, ayudan a situar un poema dentro de una atmósfera clásica, o en citas explícitas a modo de reflexiones, referencias o recreaciones literarias. Por ejemplo, al viajar por la región portuguesa de Amarante, detenido en un rincón campesino del centro del país, medita sobre las cualidades polivalentes y universales del héroe de la Odisea:

Un día Ulises dejó la esteva del arado para ir a la guerra, hizo del leño de sus bosques un corvo navío de negra proa, convirtió la esteva en remo y partió a luchar, y rendida Troya volvió a sus lares, y de nuevo el remo se hizo esteva, y por las noches, cabe el hogar, contemplando el onduleo de las llamas de fuego que le recordaban el vaivén de las olas marinas, contaba a sus hijos y nietos los trances de la guerra y de sus errabundas navegaciones. Así Portugal ${ }^{22}$.

Necesidad de acción y deseo de narrar serán, como veremos, los dos elementos más presentes en sus referencias homéricas. Pero menudean también en sus obras, en cantidad nada despreciable, alusiones más concretas. Así, al rememorar una excursión por la costa norte de Mallorca ${ }^{23}$, revive la contemplación del panorama que puede otearse desde el bosque de Miramar, en el que habitó Ramon Llull, y se deja impresionar por la Foradada, un brazo de tierra que se adentra en el mar y que se retuerce, haciendo notar que en su extremo la roca agujereada (que es lo que significa su nombre) semeja «el ojo tímido de un dragón que huye vencido a sepultarse en el mar» ${ }^{24}$. Y añade:

[La roca] deja ver en el fondo de su ojo al cielo tocando el nacarado océano. Y nos habla de los monstruos de la Odisea. Porque aquél es el mar homérico, el mar de color de vino, el de Escila y Caribdis, no el mar tenebroso de Camoens, el de Adamastor ${ }^{25}$.

En un artículo fechado en 1902, titulado «España-Perejil y la isla de Calipso» ${ }^{26}$, nuestro autor se hace eco de la teoría del estudioso francés Víctor Bérard, el investigador de las rutas de Ulises, que identificó Ogigia, la isla de la encantadora diosa

${ }^{22}$ Del capítulo titulado «Las sombras», de Teixeira de Pascoaes, Salamanca, febrero de 1908, en PTPE, OC., I, p. 194. En el mismo sentido llama «homéricos» a los conquistadores españoles que partieron de Castilla y que tejieron en el Nuevo Mundo una «epopeya portentosa» (en su artículo titulado «Injusticia inútil»), publicado en Las noticias, Barcelona, 5 de septiembre, 1899 (OC.,VII, p. 408). Otras refrencias homéricas en Unamuno, suscitadas en sus viajes, pueden verse en Martínez Conesa (1998).

${ }^{23}$ En su artículo «Los olivos de Valldemosa», $A V E$, OC., I, p. 451.

${ }^{24} A V E$, OC., I, p. 462. Cf. «En la isla dorada», 1916 AVE. OC., I, pp. 453-455.

${ }^{25}$ Este último nombre, cuya traducción griega podría ser «Indomable», es un ser fantástico inventado por Luis de Camoens, del que hace mención en el canto V (XXXVI / LXX) de Os Lusiadas. Lo presenta como un ser extraído de la mitología griega, un gigante de terrible aspecto. De él dice que era hijo de la Tierra, que se rebeló contra Zeus, y que acabó convertido en roca en el remoto cabo Tormentorio, después llamado de Buena Esperanza, en el extremo Sur de África, donde se juntan el Atlántico y el Índico. Este monstruo es, en el poema portugués, la encarnación de los peligros del mar de aguas turbulentas azotadas por tempestades que hunden las naves. Los monstruos homéricos, como Escila y Caribdis, por el contrario, se hallan en tierra, y el mar suele permanecer calmo. Sobre el mito, véase A. Brink, (1993). Sobre «el mar homérico», y otros promontorios en forma de dragones, véase el artículo de Unamuno titulado «En la isla dorada» (1916) AVE. OC., I, pp. 453-455.

${ }^{26}$ En Alrededor del Mundo, Madrid 27 de junio de 1902. EE, OC., VII, pp. 1347-1349. 
Calipso, la que se enamoró del astuto heleno Ulises, con el islote del Perejil, cercano a la costa de Ceuta ${ }^{27}$, un trozo de tierra en cuyo nombre ha pervivido el homérico re-

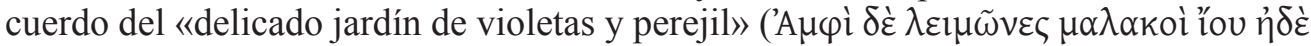
$\sigma \varepsilon \lambda$ ívou $)^{28}$ que a modo de alfombra vestía la isla y en cuyas entrañas se escondía una caverna ${ }^{29}$.

Aunque nacido en Bilbao, Unamuno descubrió realmente el mar en el agitado Atlántico de Fuerteventura ${ }^{30}$; pero siempre admiró el Mediterráneo, crisol de culturas:
Mesopotamia, Mediterráneo,
Babilonia, Asiria, Egipto, Grecia
Tigris, Eúfrates, Nilo, mar prieto,
tierra que es agua y agua que es tierra.
Mesopotamia, Mediterráneo, entre los ríos, entre las tierras, - deslindan el infinito bordes-
baja Sol desnudo en las riberas
a bañarse, sacude sal ática
espuma de rubia cabellera;
cantan los montes, cantan las fuentes, y las cigarras y los poetas, y al engendrarse sabiduría nacen los dioses y doman fieras ${ }^{31}$.

A tenor de lo que venimos apuntando, puede ya afirmarse que la atracción que siente Unamuno por Homero no tiene su centro de gravedad en la admiración bélica o en las hazañas puramente guerreras de sus héroes. Para Unamuno, «el verdadero héroe homérico, helénico, no es el bravo Aquiles, el de los pies veloces... El verdadero héroe helénico es el trapacero Ulises, fértil en astucias y en argucias» ${ }^{32}$. Se trata, ante todo, de un reflejo de la curiosidad. A través de los poemas homéricos «tan recios y tan rudos» — dice Unamuno- «se respira el culto a la inteligencia y cierta compasiva y a las veces irónica consideración a la fuerza y al valor desnudos». Al enjuiciar la dimen-

${ }^{27}$ De esta misma opinión es P. Grimal (1951: , s.u. Calipso)

${ }^{28} \mathrm{Od}$., V, 72.

${ }^{29}$ De esta caverna derivaría el nombre de la diosa que lo habitaba, Calipso (de $\left.\kappa \alpha \lambda u ́ \pi \tau \omega, ~ « o c u l t a r »\right)$. Hay así mismo una hipótesis que Unamuno recuerda en el artículo citado: del nombre fenicio $i$, «isla» y spanea, «escondrijo», derivaría el nombre Hispania.

${ }^{30}$ En su artículo «Soñando el peñón de Ifac» en El Sol , 24 de abril de 1932 (OC., I, p. 692) dice: «En mi norte cantábrico, las montañas se hunden en el mar; allí, en Levante, surgen de ella. Desde el peñón de Ifac se prende el mar latino, púnico, helénico»».

${ }^{31}$ C,. n. ${ }^{\circ} 436$; 5 de octubre, 1928; (OP, III, p. 285).

${ }^{32} \mathrm{Cf}$. «Aquiles, Ayas y Hércules», DEA. Unamuno recuerda en el artículo que la palabra «bravo» deriva de «bárbaro». 
sión bélica de la obra homérica, sentencia: «El heroísmo es, ante todo, inteligencia» ${ }^{33}$, aunque ésta sea de un tipo cercano a la astucia, aquella a la que los griegos llamaron $\mu$ ń́ ıட. A la hora de entender la consideración de Unamuno sobre el mundo helénico, uno de los más esclarecedores artículos es el titulado «La Grecia de Carrillo» ${ }^{34}$, donde expone de una manera clara sus ideas esenciales acerca de la Helenidad: En el espíritu griego - afirma - las calamidades, las guerras, las hazañas, ocurren para que de ello se hable, para conservar su memoria, una forma de inmortalidad por la fama, aunque este tipo de inmortalidad sea para Unamuno un débil remedo de aquella a la que él siempre aspiró. Por ello, piensa que las palabras de Ulises dirigidas a los feacios acerca del desgraciado castigo de Tántalo, a quien conoce en su bajada al Hades, podrían servir al desgraciado héroe de consuelo, porque

El consuelo de los condenados es que se hable de ellos aquí, en la tierra en que vivieron sin poder digerir la dicha o la desgracia, y su mayor preocupación es que no los calumniemos los vivos ${ }^{35}$.

En un artículo publicado ${ }^{36}$ una década antes que Niebla, ya apuntaba una idea que desarrollará fecundamente en esta original novela, la que se refiere a la preponderancia del elemento narrativo sobre la acción, como puede verse en los poemas homéricos, y razón última de la obra. Dice así:

Aquiles y Homero no se entienden, y en el fondo se desprecian mutuamente: para Aquiles es Homero un cronista de sus hazañas al que debe poco, y para Homero es Aquiles una ocasión de ejercitar su fantasía ${ }^{37}$.

De esta manera profundiza en la relación autor-personaje, acercando ambos planos, pero sobrevalorando el personaje y el poema sobre el autor y el poeta, y así mismo, la hazaña sobre el héroe. Para Unamuno, sin duda, el lógos — palabra, razón y sabiduría - cifra la excelencia de la cultura griega, porque lo que caracteriza a ésta es la «pasión del conocimiento» y el «ansia de saber». Y el contar que proporciona el discurso del lógos es una forma de saber placentero: «Leed los poemas homéricos — dice-, y allí veréis con qué complacencia se detienen los héroes a contar y oír contar historias.» A partir de estos supuestos podemos entender fácilmente que, para Unamuno, la atracción que ofrece el famoso episodio homérico de las sirenas ${ }^{38}$ reside (y en esto no hace sino seguir una larga tradición) no en la lujuria que se desprende de unas bellas y

${ }^{33}$ Ibídem. p. 864 .

${ }^{34}$ Se trata de una larga reseña del libro de Gómez Carrillo (1908). CEA, OC., III, pp 515-519.

${ }^{35}$ En este pasaje se hace sentir la influencia de Dante. Tántalo, pp. 849-850. Sobre esta figura, cf. infra.

${ }^{36}$ El titulado «Políticos y literatos», en La prensa, Buenos Aires, 1 de enero, 1904. EE, OC., VII, p. 781.

${ }^{37}$ La misma idea se encuentra en su relato «Y va de cuento»: «Pregunta.- "Qué es un héroe?" Respuesta.- "Uno que da ocasión a que se pueda escribir sobre él un poema épico, un epinicio, un epitafio, un cuento, un epigrama, o siquiera una gacetilla o una mera frase". Aquiles es héroe porque le hizo tal Homero, o quien fuese, al componer la Ilíada».

${ }^{38}$ Cf. Od., XII, pp. 184-191. 
sensuales criaturas, sino en el conocimiento que emana de estas seductoras cantoras ${ }^{39}$, siendo como son además las sirenas sabedoras de la fama de los héroes de la guerra de Troya (la forma de inmortalidad homérica) y de «cuanto ocurre en la fecunda tierra». Unamuno recuerda, traduciéndolas, las tentadoras palabras con las que las homéricas sirenas se dirigieron al héroe:

Ven acá famoso Ulises, gloria de los aqueos; detén la nave para oír nuestro relato. Nunca pasó nadie por aquí de largo en su negra nave sin haber oído el canto de nuestras bocas, recreándose con él y marchándose sabiendo más de lo que sabía ${ }^{40}$.

Por tanto - concluye - es la tentación del conocimiento, de la curiosidad, como en el mito de Pandora, la principal fuente de atracción que pone en peligro al héroe, un peligro que, sin embargo (por decirlo con palabras de Hölderlin) puede salvar. Desde esta perspectiva, la de la primacía del lógos, la sentencia homérica que más reitera D. Miguel, y a la que vuelve una vez y otra, es aquella que dice: Los dioses traman y cumplen la destrucción de los hombres para que los venideros tengan algo que can$\operatorname{tar}^{41}$, sentencia cuya valoración, sin embargo, irá cambiando con el tiempo, como puede constatarse en el siguiente texto, correspondiente al Diario íntimo de nuestro autor:

Tuve por mucho tiempo en mi cuarto de estudio dos cartones, un retrato de Spencer y otro de Homero, hechos por mí, a cuyo pié había copiado aquellos versos de su Odisea que dicen que los dioses traman y cumplen la destrucción de los hombres para que nos venideros tengan qué cantar. Quintaesencia del vano espíritu pagano, del estéril esteticismo que mata toda sustancia espiritual y toda belleza ${ }^{42}$.

\section{UNAMUNO, HOMERO Y LA INMORTALIDAD}

¿Por qué quien proclama que en Homero «la suprema flor de inteligencia de amor es la belleza» ${ }^{43}$ dice también que la poesía homérica mata toda belleza al tiempo que toda sustancia espiritual? Sin duda, porque el Unamuno agónico (seguimos por supuesto las categorías establecidas por C. Blanco Aguinaga) va alternándose con el Unamuno contemplativo, pretendiendo dejar de lado todo aquello que pudiera introducir una distracción en su severa y obsesiva búsqueda de la inmortalidad. Será el

${ }^{39}$ Tradición que se halla ya en Cicerón, en su obra Del supremo bien y del supremo mal, V, 18, 49, donde dice: «... No parece que fuera con la dulzura de su voz, ni con la novedad y variedad de sus cantos con lo que solían atraer [las sirenas] a quienes navegaban cerca de ellas, sino porque declaraban saber muchas cosas, de suerte que los hombres quedaban atrapados en sus rocas por la pasión de aprender». Trad. V.J. Herrero. Sobre este aspecto del mito, véase García Gual (2014: 29-40).

${ }^{40}$ Od. XII, 184-188.

${ }^{41}$ Palabras de Alcinoo, rey de los feacios en la Odisea, VIII, pp. 579-580. El pasaje, citado en muchos sitios, se encuentra, entre otros, en el artículo «La nube de la guerra o la Helena de Eurípides», OC., VII, p. 497. Cf. infra, n. 43.

${ }^{42}$ DI., cuaderno I, p. 7. Ed. González López, Salamanca 2012, p. 75 y n. 9.

${ }^{43}$ En su artículo, «Aquiles, Ayas...», cf. n. 32. 
Unamuno agónico el que acabe impregnando prácticamente toda su visión teórica de Homero $^{44}$. En efecto, acabó enfrentándose a los poemas homéricos principalmente desde sus referencias al «más allá», casi exclusivamente bajo este prisma. Se dejó llevar por su deseo de imaginar el mundo de ultratumba, y para adentrarse en el imaginario griego no dudó en adentrarse en la mitología ${ }^{45}$. Desde esta perspectiva, resulta de especial relevancia las impresiones que siempre le sugirieron las experiencias con que se topó Ulises en su viaje al Hades, en la llamada Nekyia del canto XI de la Odisea. Muy significativo - e incluso personal- le resultará en este sentido el tema del $\dot{\alpha} \sigma \varphi o ́ \delta \varepsilon \lambda \omega v \lambda \varepsilon \imath \mu \omega ́ v$, el «prado de asfódelos» que, según la geografía mítica, se halla en el Hades detrás del bosque de Perséfone. En los dos pasajes de la Odisea ${ }^{46}$ en que se habla de este lugar puede vislumbrarse parte del imaginario indoeuropeo heredado, en especial, aquel que presenta el mundo del más allá como una pradera en la que pueden alternar altos chopos, estériles sauces y la extraña presencia de una flor como el asfódelo. Se ha señalado frecuentemente la dificultad de entender que, en un hábitat húmedo, como es la pradera, arraigue una planta de terrenos áridos y pedregosos, como es el asfódelo. Esta planta, perteneciente a la familia de las liliáceas, al hundir sus profundas raíces bajo tierra, queda convertida en una figura de mediación entre el mundo solar de los vivos y el subterráneo de los muertos. Así lo expresa el poeta Yorgos Seferis, cuando se pregunta «¿cómo hablar con los muertos?» sin asfódelos, violetas ni jacintos, porque «los muertos sólo saben el lenguaje de las flores, por eso callan... en el reino de los sueños» ${ }^{47}$. Según Hesíodo ${ }^{48}$, su bulbo comestible convierte a la planta en comida de pobres. El hecho de que brote en primavera y se marchite en otoño (como la generación de las hojas y de los hombres...) ha llevado incluso a la hipótesis de que los estas plantas ${ }^{49}$ sirvieran como contrapunto a Homero para impregnar de pesimismo la morada plácida, verde y húmeda de ultratumba ${ }^{50}$. Estudiosos como J. Murr ${ }^{51}$, han considerado que «el colorido grisáceo de sus hojas y los pétalos amarillentos y violáceos de sus flores... se adecuarían bien al pálido reino de la muerte». En cualquier caso, la imagen de la pradera de asfódelos resulta para Unamuno un asunto personal, porque el nombre de la planta se relaciona con su propio apellido, ya que en euskera una significa «gamón» o «gamona», el nombre popular del «asfódelo», nombre helénico que dicen los libros de Botánica, y muno, «monte» ${ }^{52}$. Su apellido

${ }^{44}$ Así lo dice en $V D Q S$, II, LXXIV: «Si fue sueño y vanidad tu ansia de vida eterna [dice dirigiéndose a D. Quijote], toda la verdad se encierra en aquellos versos de la Odisea: Los dioses traman y cumplen...». Cf. RNM, OC., I, p. 95.

${ }^{45}$ «iMitología! Acaso; pero hay que mitologizar respecto a la otra vida como en tiempos de Platón», dice en $S T$, X (OC., VII, p. 261).

${ }^{46} O d$., XI, p. 539; p. 753.

${ }^{47}$ Seferis, «Estratis el marinero entre los agapantos», en Diario de a bordo II. Trad. P. Bádenas. Sobre las flores como elementos mediadores entre vivos y muertos en la poesía de Seferis, véase González Serrano (2000-2001: 105-120).

${ }^{48}$ Hesíodo, Op., p. 40 ss.

${ }^{49}$ Cf. Velasco (2000: 97-112).

${ }^{50} \mathrm{Cf}$. Velasco (2000: 110-111).

${ }^{51}$ En Die Pflanzenwelt in der griechischen Mythologie, p. 240 ss., citado por Velasco (2000-2001, 109-110).

${ }^{52}$ En su artículo «Ensueños lingüísticos de madrugada», fechado en mayo de 1935. 
paterno, por consiguiente, haría referencia al escenario por donde vagan las almas de los muertos ${ }^{53}$. Y así, consciente de su significado, canta:
Una, gamona, asfódelo
de mi paterno apellido,
mitológico consuelo
de la patria del olvido ${ }^{54}$.

El consuelo (tan sólo consuelo) mitológico del más allá homérico en tanto que «patria del olvido», es sin embargo insuficiente para los anhelos de Unamuno, para quien una vida despojada de memoria al otro lado de la laguna del Leteo no es sino otra cara de la muerte. En otro poema del Cancionero ${ }^{55}$ insiste en el tema:
Entre los robles, gamones,
cirios del campo, de luto;
abogallas $^{56}$, que no fruto
en retoños cimarrones.

Se ha considerado en estos versos, que guardan cierto parecido con un haiku, una contraposición simbólica de dos planos: el que remite a la vida pasada del autor, simbolizada por los gamones de Bilbao, y la presente, simbolizada por los robles de Salamanca $^{57}$. En tal sentido, cuando alude a las abogallas del roble, de las que se extrae la tinta, haría referencia a la parte de su vida marcada por su mayor obra creativa, la que tiene lugar en la ciudad del Tormes ${ }^{58}$, es decir, a su obra, otra forma de inmortalidad, para Unamuno también insuficiente, tan solo un consuelo.

Al trazar en Del sentimiento trágico de la vida, su obra capital, una breve historia de la idea del «deseo de inmortalidad», Unamuno reflexiona sobre todo aquello que, en lo referente al mundo de ultratumba, ha trazado la religión homérica. Para D. Miguel, la cultura griega es la descubridora de la muerte (desde el punto de vista de su visceral rechazo), pues — señala acertadamente - hay un antes y un después de Homero. Hablando del ansia de inmortalidad dice: «No aparece este anhelo en los poemas homéricos, que no son algo inicial, sino final: no el arranque, sino el término de una civilización. Ellos marcan el paso de la vieja religión de la Naturaleza, la de Zeus, a la religión más espiritualista de Apolo, la de la redención ${ }^{59}$. Siguiendo a Erwin Rhode, distingue con acierto la religión olímpica de las formas religiosas del orfismo, de carácter popular,

${ }^{53}$ Otros autores, sin embargo, no comparten esta etimología. Así Enrique Knörr Borrás, que la cree a partir de «unai», «vaquero», y «muno», «loma» o «colina»: «loma del vaquero», en Juaristi (2012: 31).

${ }^{54} \mathrm{Cn} .^{\circ} 289$ (OP., III, pp. 213-214).

${ }^{55} \mathrm{Cn} .^{\text {o }} 1527$ (OP III., pp. 658-659).

${ }^{56}$ Nombre que se da en Salamanca a las excrecencias del roble. También reciben el nombre de «agallas».

${ }^{57}$ C n. ${ }^{\circ} 1527,17$ de agosto, 1930 (OC., III, pp. 658-659).

${ }^{58}$ Sigue así el poema: «Fruto? Semilla?, dan tinta / que si no entra por la boca/ del hombre, al hombre le toca/ el alma y la deja encinta». Y concluye con esta contraposición de planos: «Ay gamones y abogallas / del matorral del Zarzoso [Lugar de la Peña de Francia, en Salamanca] / os grabaron en el poso / de mi visión mis batallas».

${ }^{59}$ ST, IV (OC., VII, p. 144). 
y que buscan una vida más allá de la vida. Incluye la efímera vida inconsistente del alma en el Hades homérico como parte del llamado «pesimismo griego», porque por su propia configuración, el más allá homérico no puede ofrecerle una perspectiva que colme sus expectativas de inmortalidad. La supervivencia de la $\psi \cup x \eta ́$ como una pálida sombra sin conciencia que revolotea en un lugar lóbrego, no es la inmortalidad ansiada por el hombre de carne y hueso. La inmortalidad del mundo homérico no es sino un sueño evanescente:

El que duerme, vive, pero no tiene conciencia de sí; ¿y apetecerá nadie su sueño así eterno? Cuando Circe recomienda a Ulises que baje a la morada de los muertos, a consultar al adivino Tiresias, dícele que éste es allí, entre las sombras de los muertos, el único que tiene sentido, pues los demás se agitan como sombras (Odisea X, 487-495). $\mathrm{Y}$ es que los otros, aparte de Tiresias, ¿vencieron a la muerte? ¿Es vencerla acaso errar así como sombras sin sentido? ${ }^{60}$

Nuestro autor presta también atención a un pasaje del canto XI de la Odisea, aquel en que Aquiles le dice a Ulises que preferiría ser entre los vivos de la tierra «gañán a soldada de otro, de un amo pobre y sin medios de vida, a reinar entre los muertos ${ }^{61}$. Unamuno, justo al contrario, subordina el vitalismo que el mundo homérico otorga a la vida terrena, consecuencia de la poca esperanza depositada en las sombras del más allá, a una vida eterna. Por ello, la llamada 'vitalidad homérica', para él tan sólo es una creencia hipertrófica:

Y sucede que a medida que se cree menos en el alma, es decir, en su inmortalidad consciente, personal y concreta, se exagerará más el valor de la pobre vida pasajera. ${ }^{62}$

Hay un episodio en la Odisea que sin duda llamó la atención de Unamuno, aquel en que la diosa Calipso le ofrece a Ulises, a cambio de permanecer como amante para siempre junto a ella en la isla Ogigia, una inmortalidad personal y consciente exenta de pasar por el trance de la muerte, propuesta que asombrósamente, el héroe rechaza ${ }^{63}$. Una de las razones que podrían explicar la tristeza en que se sumió Calipso, según Unamuno, radicaría en la imposibilidad de suicidarse debido a su condición de diosa. Resulta extraño, sin embargo, que nuestro autor, al hilo de este episodio, no haya ahondado de manera más explícita acerca de la misteriosa renuncia de Ulises a la inmortalidad que la bella diosa le ofrece. Se puede conjeturar, no obstante, lo que en realidad pensaría Unamuno acerca de esta renuncia a partir de su propio discurso: su deseo de una vida eterna y a la vez temporal. Puesto que la inmortalidad de los dioses griegos llevaba aparejada la eterna juventud, conllevaría también la imposibilidad de

${ }^{60} S T$, X (OC., VII, p. 246).

${ }^{61}$ Od. XI, pp. 487-488.

${ }^{62} S T$, I (OC., VII, p. 116).

${ }^{63}$ A este episodio se refieren estas palabras de Del sentimiento...: «Y aun imaginada una inmortalidad personal, ¿no cabe que la sintamos como algo tan terrible como su negación?». A continuación cita estas palabras del Telémaco del escritor francés Fenelón: «Calipso no podía consolarse de la marcha de Ulises; en su dolor, hallábase desolada de ser inmortal». ST, X (OC., VII, p. 241). 
cambio, y por tanto, la exención estricta de la temporalidad, un modelo totalmente incompatible con el modelo de inmortalidad que D. Miguel siempre anheló: una vida temporal y eterna al mismo tiempo. Tradicionalmente, y de manera secundaria, se ha explicado también la renuncia de Ulises a la invitación de Calipso por la importancia que para el héroe homérico tiene la fama — una forma de inmortalidad - algo que, encerrado para siempre en la isla, no podría dar a conocer. Ni que decir tiene que este tipo de inmortalidad no sería para Unamuno sino un sucedáneo, un remedo de la vida por él deseada, la de la inmoralidad de carne y hueso.

En un artículo titulado Tántalo ${ }^{64}$ en el que trata acerca de la conocida figura mítica de quien sufrió un castigo eterno en el Hades, el autor refleja así mismo hondas reflexiones en relación con sus particulares deseos. A través del mito, muestra un pensamiento propio muy definido. Así traduce Unamuno el pasaje de la Odisea ${ }^{65}$ referido a este personaje trágico:

También vi a Tántalo, presa de acerbos dolores, de pie en la laguna. Llegábale ésta a la barba, y él, de pie y sediento, no puede tomar de beber en ella. Cuantas veces se encorva el anciano, anhelando beber, otras tantas se le escapa el agua y aparécesele a los pies la tierra negra, que un dios enjuga. Unos altos árboles echan de lo alto fruta, peras, granadas y manzanas brillantes, dulces higos y lozanas aceitunas, y cuando el viejo se dirige a cogerlas con sus manos, el viento las arrebata a las nieblas tenebrosas.

¿Cuál fue, según el mito, la culpa de Tántalo, el hijo de Zeus y Pluto, antiguo y venturoso rey de Lidia, para merecer semejante castigo? Píndaro ${ }^{66}$ recuerda la versión según la cual habría matado y despedazado a su hijo Pélope para servirlo a los dioses en un festín, pero, acaba decantándose ${ }^{67}$ por aquella, según la cual, había robado y compartido con sus semejantes el néctar y la ambrosía («el vino y el pan de la inmortalidad, la bebida y el manjar con que uno se hace imperecedero» ${ }^{68}$ ) que, como privilegio, sólo a él la divinidad le había invitado a probar. Unamuno alaba su elección a la hora de tratar poéticamente el mito. Y glosa así las poéticas palabras del piadoso poeta

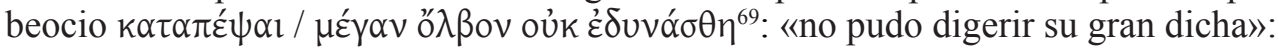

Tántalo, no pudiendo digerir su gran dicha, la quiso eterna y dársela eterna a los pobres hombres; robó para ello a los dioses el néctar y la ambrosía, y los dioses le hicieron inmortal, pero, a cambio del néctar, no puede, sediento, coger con sus secos y escarriados labios el agua de la laguna en que vive sumergido, y a cambio de la ambrosía, no alcanza con sus manos los frutos de los árboles que le dan sombra. El robado licor de la inmortalidad le llena de una sed eterna, y de un hambre eterna el robado manjar de la inmortalidad ${ }^{70}$.

${ }^{64}$ Publicado en «Los lunes del Imparcial», Madrid, 2-VIII-1909. OC., IX, p. 847-853.

${ }^{65}$ Od., XI, pp. 582-592.

${ }^{66}$ Píndaro, Ol., I, pp. 37-41. Cf, Apolodoro, Ep. 2, 3.

${ }^{67}$ Pindaro,Ol., I, pp. 61-64. Cf. Apolodoro, Ep. 2 ,1.

${ }^{68}$ Unamuno, Art. Cit. p. 848

${ }^{69}$ Píndaro, Ol., I, pp. 55-56.

${ }^{70}$ Unamuno, Art. Cit. p. 849. 
Para Unamuno ésta es la razón del castigo, razón que guarda ciertas resonancias prometeicas, porque «No pudiendo digerir su gran dicha, la quiso eterna y dársela eterna a los pobres hombres», labrando así de manera catastrófica su propia ruina. $\mathrm{La}$ dimensión trágica que Unamuno otorga al personaje de Tántalo, del que los humanos seguimos hablando, es la manera en que afronta su propio destino, de un modo parecido a la grandeza que distingue a Calipso y que presagia la de Prometeo: «La inmortalidad del dolor. Que es acaso la única posible» $\rangle^{71}$. El mito de Tántalo implica no obstante una paradoja trágica: «El robado licor de la inmortalidad le llena de una sed eterna, y de un hambre eterna el robado manjar de la inmortalidad $»^{72}$. También a los hombres nos sucede - dice- que «sufrimos sed sin necesitar agua, y el alma es la que sufre». La semblanza que traza del trágico personaje acaba así: «¿No es la esperanza acaso el alimento de tu eterna angustia? ¿No es ella, no es la esperanza, la que te impide morir de sed? $\gg^{73}$.

El tema de la esperanza, más aún que el de la rebeldía o el absurdo es, por lo demás, el que para Unamuno importa en el tratamiento de la figura de otro condenado en el Hades, Sísifo ${ }^{74}$. Así se describe su castigo en la Odisea:

Advertí luego a Sísifo, presa de recias torturas.

Iba a fuerza de brazos moviendo un peñón monstruoso

y, apoyándose en manos y pies, empujaba su carga

hasta el pico de un monte; mas luego, llegado ya a punto

de dejarla en la cumbre, la echaba hacia atrás su gran peso;

dando vueltas la impúdica piedra, llegaba hasta el llano

y él tornaba a empujarla con todas sus fuerzas. Caía

el sudor de sus miembros y el polvo envolvía su cabeza ${ }^{75}$.

Varios son los motivos míticos que la tradición ofrece como causa de su castigo: Según la Ilíada ${ }^{76}$, Sísifo habría revelado al río Asopo el rapto de su hija Egina por parte de Zeus; a cambio de esta información, Sísifo, «el más astuto de los hombres», consiguió que el dios-río proporcionara agua a la ciudad de Corinto, de la que era rey. Zeus envió a la Muerte (Tánatos) para que castigara al delator, pero Sísifo hizo a ésta prisionera, dándose así la circunstancia de que durante algún tiempo no muriera nadie. Plutón envió entonces pidió ayuda a Ares, el dios de la guerra, que liberó a la Muerte. Entonces fue llevado al Hades, pero, en otro alarde de astucia, había ordenado previamente a su esposa Mérope que no le hiciera ofrendas fúnebres, y con esta excusa convenció a Plutón, el dios de los muertos, para que le permitiera volver a tierra con el fin de reprender a su incumplidora esposa. No volvió sin embargo al mundo de los

${ }^{71}$ Unamuno, Art. Cit. p. 842.

${ }^{72}$ Unamuno, Art. Cit. p. 849.

${ }^{73}$ Unamuno, Art. Cit. p. 853.

${ }^{74}$ Después de Homero, la fuente mitográfica más antigua es Ferécides, 3 F 119. Cf. Apolodoro, I, 7,$3 ; 9,3 ;$ III, 4, $3 ; 10,1 ; 12,6$.

${ }^{75}$ Od. XI, 593-600. Trad. J.M. Pabón.

${ }^{76} \mathrm{Il}$. VI, p. 153. 
muertos hasta que la Vejez lo devolvió allí irremisiblemente a una avanzada edad. Todo ello le acarreó el castigo descrito por Homero.

El filósofo Albert Camus escribió un importante ensayo sobre esta figura mítica. Para el filósofo francés, su «desprecio de los dioses, su odio a la muerte y su apasionamiento por la vida le valieron ese suplicio indecible en el que todo el ser se dedica a no acabar nada». «Es el precio — añade — que hay que pagar por las pasiones de esta tierra» ${ }^{77}$. Los dioses — sigue Camus - «habían pensado con algún fundamento que no hay castigo más terrible que el trabajo inútil y sin esperanza» ${ }^{78}$.

¿En qué consistiría, en efecto, su castigo si a cada paso le sostuviera la esperanza de conseguir su propósito? El obrero actual trabaja durante todos los días de su vida en las mismas tareas y ese destino no es menos absurdo. Pero no es trágico sino en los raros momentos en que se hace consciente ${ }^{79}$.

Por ello, Sísifo es «el héroe del absurdo $»^{80}$. Pero además, para Camus, este mito es trágico porque el protagonista tiene conciencia del castigo, un castigo sin esperanza, que sin embargo, no impide que la vida deba ser vivida. Es preciso - dice Camusimaginarse a Sísifo como dichoso. Su destino le pertenece ${ }^{81}$. Y así actúa consecuentemente, sine metu et sine spe.

Unamuno compuso su poema Sísifo partiendo de la imagen que ofrece el final de

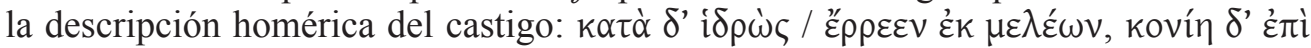

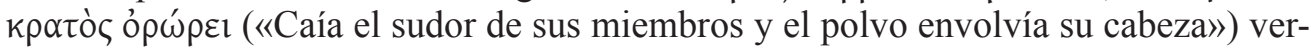
sos que pone como lema al principio del poema. Dice así:

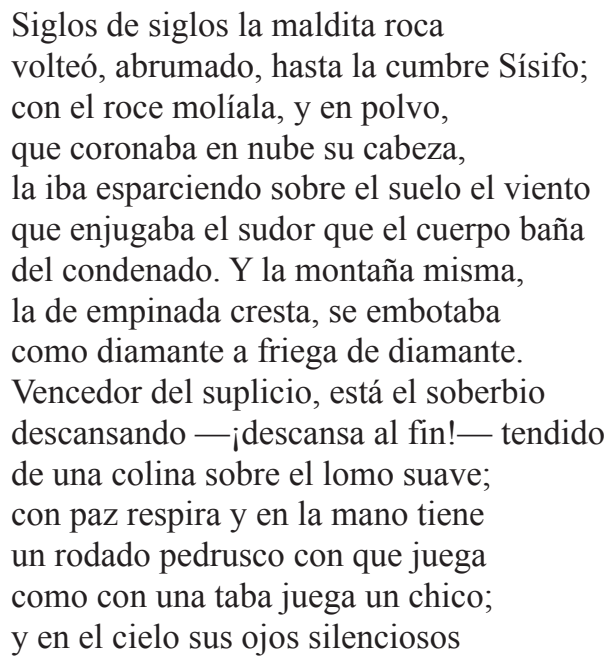

\footnotetext{
${ }^{77}$ Camus (1951: 158-159).

${ }^{78}$ Camus (1951: 157).

${ }^{79}$ Camus (1951: 159-160).

${ }^{80}$ Camus (1951: 158).

${ }^{81}$ Camus (1951: 161).
} 
fijando sin rencor, decir parece:

«Se acaba todo, ;oh Jove!, hasta la pena» ${ }^{82}$.

Como puede apreciarse, el Sísifo unamuniano coincide con el camusiano en la conciencia trágica de su castigo. Sin embargo, media una diferencia fundamental: para D. Miguel, la rebeldía no desemboca necesariamnte en una pasión inútil, porque la esperanza, nacida de la desesperación, es capaz al fin de vencer al absurdo. Para Unamuno, a diferencia de Camus, la aceptación de la finitud humana en modo alguno puede ser una forma de rebeldía, sino que para él, rebeldía sería precisamente todo lo contrario ${ }^{83}$.

Como puede verse, son ahora los pasajes de Calipso, Tántalo y Sísifo los que cobran importancia para Unamuno agónico, o en cualquier caso, los que se sobreponen a otros temas en los que sólo halla la belleza diletante, «el estéril esteticismo» que quiere alejar de sí para que no perturbe, en la brevedad de la vida, su grave reflexión sobre el más allá ${ }^{84}$. Por lo demás, para D. Miguel no hay mayor belleza que el pensamiento (puesto al servicio de la búsqueda de la inmortalidad), como indican estos versos en que define el ideario y tarea del poeta:

No te cuides en exceso del ropaje, de escultor y no de sastre es tu tarea, no te olvides de que nunca más hermosa que desnuda está la idea...

Busca líneas de desnudo, que aunque trates de envolvernos en lo vago de la niebla, aun la niebla tiene líneas y se esculpe; Ten, pues, ojo, no las pierdas

Que tus cantos sean cantos esculpidos, ancla en tierra mientras tanto que se elevan, el lenguaje es ante todo pensamiento y es pensada su belleza ${ }^{85}$.

${ }^{82}$ P. PC., I, pp. 181-182.

${ }^{83}$ Recordemos, en este sentido, el primer cuarteto de su soneto ¿Por qué me has abandonado?, Salamanca, 9 de diciembre, 1910, RSL,CXIII (OP., I, 330) : «Por si no hay otra vida después de ésta / haz de modo que sea una injusticia / nuestra aniquilación; de la avaricia / de Dios sea tu vida una protesta».

${ }^{84}$ En relación con su postura anti-estetizante, Josep Pla, quien coincidió con Unamuno cuando éste se hallaba exiliado en París cuenta una anécdota que explica perfectamente la postura de D. Miguel ante el mundo clásico: «Vivía Unamuno aislado de sí y ensimismado en su permanente cavilación, cerrado a un mundo sobre el que sólo tendía sus antenas intelectuales y a resguardo de acceder a él mediante la sensualidad. Absolutamente nada era capaz de arrancarle de su ermita íntima. Un día del exilio parisino y como pasara junto al Museo del Louvre, le propuso Pla visitar la sala de escultura griega. La respuesta de Unamuno fue fulminante: No, no; no puedo distraerme». [Citado por Azúa (1998: 213)].

85 «Credo poético», P. (OP., I, p. 53). 


\section{LA AMBIVALENCIA DE HELENA}

La fluctuación entre la atracción de la belleza y el desprecio del «estéril esteticismo» que Unamuno percibe en la obra de Homero - aspectos contrarios y sin embargo reales de su visión - puede seguirse también al hilo del tratamiento que hace de la figura mítica de Helena, la mujer que se sabía a sí misma — como le gustaba recordar a Unamuno- «materia digna de canto para los hombres venideros» ${ }^{86}$. Es, sin duda, el personaje que simboliza el amor-odio que - así mismo de modo contradictorioacabó desarrollando D. Miguel en su vivencia del mundo clásico. Dice así en sus Recuerdos de niñez y mocedad:

Bajo el pulido cielo de la Jonia el viejo cantor canta el rencor de Aquiles, el de los pies veloces, y a los cabelludos aqueos que pelean contra la sagrada Troya por aquella divina Elena [sic], cara de perro, esposa del rubio Menelao. Y cuando los prudentes ancianos de la ciudad de Príamo acuden a las Puertas a presenciar el singular combate entre el divino Paris y el rubio Menelao, y chachareando como cigarras que posadas en los árboles del bosque dan su voz al aire, vean a Elena acercarse a la torre, se dicen los unos a los otros: 'No debe causar indignación el que los troyanos y los cabelludos aqueos sufran dolores durante tan largo tiempo por semejante mujer; se parece terriblemente en su rostro a las diosas inmortales'. Así comprendía que peleen los hombres por la belleza, y por la belleza encarnada en mujer, aquel ciego cuya mirada, tan serena como el cielo de la Jonia, penetraba con maravillosa intuición en las almas infantiles de sus héroes ${ }^{87}$.

Albert Camus, que tenía hondas raíces mediterráneas, escribió en su libro Verano un bello ensayo titulado El destierro de Helena (1948) en el que añora la conquista de la belleza. Considera que el sentido trágico del Mediterráneo es, a diferencia del que emana de las brumas nórdicas, un mundo solar lleno de belleza. Esta belleza puede llegar adquirir - por inalcanzable - algo de opresivo e incluso desencadenar la tragedia. Pero en el ideal de la belleza griego reina ante todo la noción de límite y la medida. En el mundo actual, por el contrario, predomina el deseo de lo absoluto y el imperio de las cosas. A diferencia de los griegos, proclama Camus: «Hemos desterrado a la belleza. Los griegos en cambio tomaron armas por ella». Y en dos pasajes significativos añade:

Diga nuestro mundo lo que dijere, lo cierto es que deserta del mundo. Ulises retenido por Calipso pudo elegir entre la inmortalidad y la tierra de su patria. Eligió la tierra y con ella la muerte. Una grandeza tan sencilla nos es hoy ajena. Otros dirán que nos falta humildad.

Rechazar el fanatismo, reconocer la propia ignorancia, los límites del mundo y del hombre, el rostro amado, la belleza, en fin, he ahí el campo donde podremos reunirnos con los griegos.

\footnotetext{
${ }^{86} \mathrm{Il}$., VI, 358.

${ }^{87}$ RNM, (OC., VIII, p. 155).
} 
El mito del rapto de Helena narra, en efecto, cómo los griegos tomaron las armas por la belleza. Pero en la Europa marcada por el tormentoso siglo Xx - sigue Camus - se lucha solo a cañonazos por lo más desmedido, lo menos bello y lo más monstruoso. También Unamuno, quien «comprendía que peleen los hombres por la belleza», por una terrible -aivó́ - «por la belleza encarnada en mujer», irá ajustando esta noble idea del mito e irá alternándola con otras. En efecto, en su artículo Aquiles, Ayas [sic], Hércules, del que ya hemos hecho mención ${ }^{88}$, tras comentar la historia de amor de la reina portuguesa Inés de Castro, «divina mujer, verdadera encarnación de la inteligencia más subida, de la inteligencia de amor», según puede leerse en la obra del escritor luso Antero de Figueiredo titulada Don Pedro e doña Inés, compara a esta dama con la homérica Helena, «una verdadera encarnación de la inteligencia, que es la belleza». Pero esta idea irá evolucionando (o involucionando) hacia otras más abstractas, o más deshumanizadas, como la que presenta a Helena como la mujer que hace que los hombres se peleen terriblemente por algo que en el fondo no es sino un espejismo, una quimera, o una nube, como tan bien ha quedado en la Helena, la tragedia de Eurípides, expresado. Conviene, pues, tener en cuenta el simbolismo de la Helena-nube en la interpretación de Unamuno, un simbolismo forjado en gran medida a partir de elementos tomados del imaginario clásico. Ésta nube, en sustancia, llegará a ser - veremos - «más terrible dama que la carne». Hay un verso de la Ilíada ${ }^{89}$ que pronto había llamado la atención de Unamuno, y del que hace mención, junto con una cita del Génesis ${ }^{90}$ y otra del Quijote ${ }^{91}$, a la cabeza de un soneto titulado Dama de ensueño ${ }^{92}$. Al pie del poema escribe: «El pasaje de la Ilíada dice que Aquiles en su

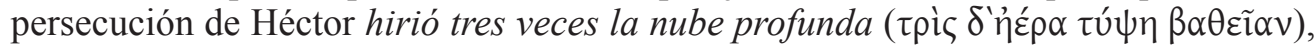
con la que Apolo le había cubierto, una especie de bruma o acaso polvareda». En el desarrollo del poema no se hace ya mención al pasaje homérico, pero, se sugiere una atmósfera que envuelve el afán de lucha contra lo imposible y el combate contra lo quimérico (como Jacob en su lucha contra el ángel o Don Quijote contra los pellejos de vino):

Dama de ensueño es más terrible dama que la de carne; el pobre anacoreta rendido, al alba, encuéntrase en la cama solo, sin el amor y el alma inquieta.

Cuando enemiga soledad le aprieta triste consúmese en la fría llama de infecundo deseo, amor no enceta ${ }^{93}$ y está gastado porque sueña que ama

\footnotetext{
${ }^{88}$ Cf. supra, n. 33.

${ }^{89}$ Il., XX, p. 446.

${ }^{90}$ Génesis, XXXII, pp. 24-30.

${ }^{91}$ Parte I, cap. XXXV.

${ }^{92}$ RSL, CXVII, fechado en Salamanca el 21 de diciembre de 1910 (OP., I, p. 333).

${ }^{93}$ Del lat. Inceptare, frecuentativo de incipere, «empezar», Dic. María Moliner.
} 
sin amor. Así tú que tu rescate buscas en las tinieblas; el combate de Jacob con el ángel, desafío con pellejos de vino que te abate cual si lucharas de verdad; tu brío gastas y quien lo traga es el vacío.

El símbolo de la nube - sutil, intangible, inalcanzable — es también para Unamuno el equivalente metafórico de la Quimera («el [mítico] monstruo de raza divina, no humana: Por delante león, por detrás serpiente/ y en medio cabra», según Homero ${ }^{94}$, que además exhalaba «la terrible furia de una ardiente llama»). Culturalmente, el sentido más común de este engendro ha quedado ligado a la idea de lo imposible e inalcanzable en la lucha, especialmente la amoros $a^{95}$. Así lo refleja nuestro autor:
Entonces me rodean los misterios
haciéndome soñar nubes fantásticas, quimeras sin contornos definidos, de ondulante perfil, figuras vagas, visiones fugitivas de otros mundos que se hacen y deshacen sin parada, sin dejarme su imagen, ni me quede estela o nimbo alguno de su marcha ${ }^{96}$.

En el artículo «La nube de la guerra o la Helena de Eurípides», que nuestro autor subtitula «disertación de un helenista sobre un tema de actualidad» ${ }^{97}$, afirma que en los poemas homéricos, la motivación última de las guerras no sería exclusivamente el factor económico, como quieren los discípulos de Karl Marx y las teorías materialistas. «Se guerrea también, y acaso más principalmente — dice- , por afirmar, tal vez imponiéndola a otros, una cultura, que suele culminar en una lengua. Se guerrea por una Helena». Es ahora la bella dama el símbolo de la cultura griega ${ }^{98}$, y a partir del mito que ofrece Eurípides ${ }^{99}$ en su tragedia Helena, versión que hunde sus raíces, no en el imaginario épico de Homero, sino en el mundo lírico — y por tanto personal — de la Palinodia de Estesícoro ${ }^{100}$, extraerá hondas consecuencias. Según esta versión, Helena no marchó en las naves griegas a Troya, sino que tan sólo viajó un e`̌ $\delta \omega \lambda o v$ fabricado

${ }^{94} \mathrm{Il}$. VI, pp. 179-182.

${ }_{95}$ Manuel de Rabanal (1972: 29-31) dice: «Entendemos hoy, en el lenguaje vivo, por quimera aquello "que se propone a la imaginación como posible o verdadero, no siéndolo". Viene, pues, toda quimera a equivaler, más o menos, a "fantasmagoría", a "ilusión", a "utopía", a "vano y disparatado ensueño"».

${ }^{96}$ «Nubes de misterio», $P$ (OP., I, pp. 147-148).

${ }^{97}$ Que no es sino la primera Guerra mundial. Está fechado en Salamanca, en septiembre de 1914, y fue publicado en Buenos Aires, en Caras y Caretas el 24-X-1914.

${ }^{98}$ Art. cit. p. 861.

${ }^{99}$ Para nuestro autor, «un sofista». Véase también su artículo «Las dos nubes», publicado en $L a$ Nación el 20 de octubre de 1915 (OC., IX, pp. 1331-1337).

${ }^{100}$ Sobre este tema y sus fuentes, vid. Ruiz de Elvira, (2001 b: 316-319. Según la leyenda, Estesícoro, autor de una Helena de tintes homéricos, cambió su versión del mito tras quedar ciego. Puede verse así 
a partir de una nube por la divinidad, por lo que la bella no pudo ser la culpable de los estragos de la contienda. La verdadera esposa de Menelao, la de «carne y hueso», habría permanecido durante el conflicto escondida en Egipto, junto a Proteo, y al acabar la guerra, la nube se habría desvanecido. Unamuno ofrece también una particular palinodia: El hecho de que la heroína de Eurípides no fuera de carne y hueso, sino fabricada por Hera, querría decir que «Helena, la cultura helénica, por la que lucharon aqueos contra troyanos, no fue sino una nube», es decir, un fantasma, una quimera, hecho del que extrae una desgarrada reflexión. En efecto, en contra de las interpretaciones tradicionales, según las cuales, la Helena no sería en rigor una tragedia, sino más bien una obra que preludia la Comedia Nueva ${ }^{101}$, Unamuno encuentra en ella un aspecto plenamente trágico, el que implica que se pelee por algo que a la postre no resulta sino una trágica quimera ${ }^{102}$ : «¿No será Helena — dice_-, y con ella la Tierra que la sustenta, una nube y no más que una nube? ¿Y merece una nube que se pierda por ella la vida?» ${ }^{103}$. Bastantes años después, el poeta griego Georgos Seferis, en su poema Helena expresará una idea muy semejante. ¿Estaba presente en Troya Helena? se pregunta el poeta. He aquí su respuesta:

En Troya, nada - una ficción.

Así lo querían los dioses.

Y Paris yacía con una sombra como si fuera una criatura viva

¡Y por Helena estuvimos degollándonos diez años!

Un inmenso dolor se abatió sobre Grecia.

Tantos cuerpos arrojados

a las fauces del mar, a las fauces de la Tierra;

Tantas almas entregadas a las muelas como el trigo en el molino.

Los ríos se crecían con la sangre en el légamo

por un ondear de lino, por una nube,

tremolar de una mariposa, plumón de cisne,

Por una túnica vacía, por una Helena ${ }^{104}$.

Siguiendo con esta especie de deconstrucción del personaje de Helena, podemos ver que Unamuno ahonda también en la encarnación de su figura en el mito de Fausto. Recordemos que este personaje mítico y literario tiene un origen real: Johann Faustus,

mismo Alsina (1957: 157-175) y el capítulo VI, titulado «La imagen». Véase también Bettini y Brillante (2002: 117-140).

${ }^{101}$ Cf. Tovar (1966: 105-138).

${ }^{102}$ Unamuno añade: «Hay veces en que el invadir es defenderse [s.c. defender una cultura]. Pero los otros no se resignan a ser invadidos, a perecer para que el invasor se conserve». Cf. Art. cit. p. 826.

${ }^{103}$ Estos aspectos han sido recreados de una manera emotiva, desde la postura de un «excombatiente», por Manuel de Rabanal (1972: 57-65), en una especie de confesión que acaba con estas palabras: «Desde mi yo y mi circunstancia permítaseme que clame que nada encuentro tan trágico en la tragedia antigua entera como esta Helena-nube por la que mueren como moscas los mozos y hombretones de una y otra ribera del pequeño mar de Odiseo». Camús (1951: 28), por su parte, dice: «Europa ya no filosofa en medio de martillazos sino de cañonazos», y Unamuno acaba su artículo con éstas: «¡Ah!, es que la vida misma es otra nube, una ilusión, un sueño. Y luchar es soñar.» (OC., VII, p. 863).

${ }^{104}$ Trad. Bádenas. En Seferis (1989: 195-196). 
un hombre extraordinario que vivió en el norte de Alemania, cerca de Wittenberg, y que practicaba la astrología, la medicina, la alquimia y otras ciencias ocultas; de él se decía también que explicaba poesía homérica en la Universidad de Erfurt, lugar donde hizo aparecer ante sus alumnos a Helena de Troya junto a otros seres del mundo antiguo. Según un temprano libro popular (el Faustbuch) titulado Historia von Dr. Johannes Fausten en el que aparece por primera vez configurado el mito, Fausto habría conjurado el fantasma de Helena, con la que se casó y tuvo un hijo. En esta versión, tanto el retoño como su madre desaparecen con la muerte de Fausto, se desvanecen como una nube. Con el tiempo el mito creció por obra de ingenio del misterioso autor isabelino Christopher Marlowe (1564-1593), quien, en 1592, compuso una tragedia barroca, La trágica historia del doctor Fausto. Unamuno, al final de Del sentimiento trágico de la vida ${ }^{105}$, destaca el pasaje en que Fausto consigue que Helena aparezca en escena de la mano Mefistófeles a petición de unos estudiantes (Esc. I; Act. V). Uno de éstos repite las palabras homéricas que tanto gustaban a Unamuno:

No es extraño que los airados griegos castigasen

con una guerra de diez años el rapto de tal reina:

$\mathrm{Su}$ celestial belleza supera cualquier parangón.

Y, al contemplar Fausto «el rostro que dio impulso a mil navíos y puso en fuego a las altas torres de Troya» exclama (en traducción de Unamuno):

Dulce Helena, hazme inmortal con un beso - y le besa- Sus labios me chupan el alma; ¡mira cómo huye! ¡Ven, Helena, ven; devuélveme el alma! Aquí quiero quedarme, porque el cielo está en estos labios, y todo lo que no es Helena, escoria es.

La Helena de Marlowe es un espíritu de belleza que, como el $\varepsilon$ ไ̌ $\delta \omega \lambda$ ov de Eurípides del que Unamuno se hace eco, se desvanece cuando quiere abrazarla, porque es tan sólo una imagen y no una mujer de carne y hueso. Pero el espíritu renacentista de Marlowe, con su descripción de los placeres terrenales («todo lo que no es Helena, escoria es»), a pesar de que condena moralmente la actitud de Fausto, refleja a la par una nueva época, aquella que no se centra en exclusiva en la salvación del alma, sino que reivindica una nueva condición, la del hombre «libre y recuperado, asentado sólo sobre sus propios pies y ya no sobre la quebradiza tabla de la fe ${ }^{106}$. Para Unamuno este ideal resultará el símbolo de Europa, en el sentido peyorativo que para él llegará a significar el concepto Europa:

Y esta Helena — se pregunta entonces nuestro autor- ¿es la esposa del rubio Menelao, la que robó Paris, y causó la guerra de Troya, y de quien los ancianos troyanos decían que no debía indignar el que se pelease por mujer que por su rostro se parecía tan terriblemente a las diosas inmortales? Creo más bien que esa Helena era otra, la que acompaña a Simón el Mago, y que éste decía ser la inteligencia divina. Y Fausto puede decirle: ¡Devuélveme el alma! Porque Helena con sus besos nos saca el alma. Y lo que

${ }^{105}$ ST. XII (OC., VII, p. 285).

106 Santoyo (1984: 25). 
queremos y necesitamos es alma, y alma de bulto y de sustancia. Pero vinieron el Renacimiento, la Reforma y la Revolución, trayéndonos a Helena, o más bien empujados por ella, y ahora nos hablan de Cultura y de Europa ${ }^{107}$.

Unamuno menciona a Simón el Mago, también llamado Simón de Gitta, un hechicero de tendencia gnóstica que habitaba en la antigua Samaría. De él se cuenta en los Hechos de los Apóstoles (8: 4-24) que intentó comprar a Pedro el poder de transmitir el Espíritu Santo con la imposición de las manos. Según la literatura posterior, Simón fue adorado como un dios e iba acompañado de una prostituta de Tiro de nombre Helena, que a su vez — decía él— era una reencarnación de la bella de Troya, y al mismo tiempo, la primera idea de Dios ( $\varepsilon^{\prime} v v o l \alpha$, en lenguaje gnóstico) a través de la que todo lo demás habría sido creado.

Un sentimiento bien distinto es el que le inspira a Unumuno el Fausto de Goethe. En el prohombre alemán, el personaje de Helena se transforma en Margarita, la mujer abnegada, pura, desinteresada y perfecta, además de madre y redentora del protagonista, aspectos todos ellos muy valorados por Unamuno. En la obra del insigne alemán, Fausto desea conocer, saber y vivir, y todo ello sin perder el alma - algo a lo que le ayuda Margarita - la mujer total (Fausto I). Pero en la otra versión (Fausto II) vuelve a aparecer la Helena que aborrece Unamuno, la que se muestra en Marlowe como un diuell, es decir, un diablo vestido de mujer. Esta es para Unamuno la Helena de la estética vacía, la que trae esa Europa decadente y estetizante, la que sólo aporta, bajo su engañosa belleza, un tecnicismo antihumanista ante el que Unamuno se rebela. Don Miguel desdeña cualquier simbolismo de tipo cultural y estético per se, como algo que en sí mismo conllevara una dimensión negativa. Las reflexiones del escritor y crítico Félix de Azúa iluminan este principio cuando llama la atención sobre un personaje de Abel Sánchez, la famosa novela de Unamuno. En esta obra, cuyo tema central es la envidia, su protagonista, Abel, un artista despreocupado y superficial, es pasto de la envidia del médico y pensador Joaquín Monegro. El artista seduce a una hermosa muchacha de la que Joaquín está enamorado y acaba casándose con ella. La muchacha, significativamente, lleva el nombre de Helena, por lo que, connotativamente, se refiere a la más hermosa de las mujeres griegas (quizá por ello escriba en este caso su nombre con hache). Esta Helena, con su belleza y lujuria, desencadenará una guerra pasional. Pues bien, es en el capítulo XX, donde se desvela el linaje completo del hijo al dar el nombre y apellidos: Abel Sánchez Puig. Sobre este detalle escribe Azúa:

Tengo para mí que Unamuno hizo de Helena una encarnación de aquella Cataluña que tanto detestó a partir de 1906, seguramente por lo mucho que le había entusiasmado en 1899. La traición de Helena, la cual abandona al agónico filósofo Monegro por un pintor superficial y artificioso (que no llama Rusiñol de puro milagro), es el trasunto de la traición de los catalanistas en quienes había visto Unamuno una posible fuerza regeneradora del país, los cuales finalmente se desinteresaron de la modernización de España y eligieron encerrase en su nación, exenta e insolidaria.

${ }^{107}$ ST, X. (OC., VII, p. 285). 
El Unamuno-Monegro atormentado por el deseo sexual de Helena-Cataluña, y envidioso de esa gente que no se la merece (los Abeles-modernistas), o quizás se la merecen cumplidamente, es sólo un estrato simbólico más en una novela que permite todas las interpretaciones ${ }^{108}$.

\section{VUELTA A ULISES}

Dicho todo lo anterior, nada impide que podamos considerar la presencia del mundo homérico en Unamuno (como lo fue también el mundo del Quijote) fuente perenne de conocimiento moral y vital. En un artículo fechado en 1918, cuando contaba 54 años, D. Miguel renueva, como el hidalgo manchego en su segunda salida, su fe en la vida, su deseo de volver a empezar de nuevo y su firme determinación de no dejarse morir, esta vez acompañado de Ulises. Así queda plasmado de manera poética en un artículo titulado El último viaje de Ulises ${ }^{109}$, en el que medita sobre el famoso poema de Lord Alfred Tennyson, el Ulysses ${ }^{110}$. El bardo inglés sigue la versión del Infierno de Dante (Canto XXVI). Ulises es aquí presentado no como alguien a quien le motiven sus aventuras, el íntimo halago de un hijo (dolcezza di figlio), la piedad de su anciano padre, y ni siquiera el amor por el que estuviera obligado ante la discreta Penélope (né 'l debito amore /lo qual dovea Penelopé far lieta); nada de ello es más fuerte que su más íntimo anhelo: su ardoroso deseo de seguir conociendo el mundo (devenir del mondo esperto). A partir de esta versión puede hablarse de todo un ciclo de recreaciones literarias, de un motivo homérico que ya desde antiguo debió intrigar a los griegos. Se trata de un tema que también trató Borges al final de su nostálgico poema titulado Odisea, libro vigésimo tercero ${ }^{111}$ y que, referido al regreso de Ulises a Ítaca, acaba así:
Ya en el amor del compartido lecho
duerme la clara reina sobre el pecho
de su rey pero, ¿dónde está aquel hombre
que en los días y noches del destierro
erraba por el mundo como un perro
y decía que Nadie era su nombre.

En su poema, Tennyson presenta a un Ulises ya viejo y ocioso que se consume en la tranquilidad del hogar, no junto a la lumbre ondulante que recuerda las olas marinas, sino junto al fuego quieto del hogar (still hearth) lugar donde, irónicamente, generaciones y generaciones han contado mil hazañas. Atrapado en medio de los áridos riscos y yermos estériles de Ítaca, junto a su mujer, ya madura (aged wife), siente que se halla solo entre gente fiera (savage race), alejada de la aventura del espíritu, que sólo piensa en atesorar, dormir y comer, y que se muestra incapaz de reconocer al héroe

\footnotetext{
${ }^{108}$ De Azúa (1998: 230-231).

${ }^{109}$ Publicado el 26 de abril de 1918 en Nuevo mundo, Madrid.

${ }^{110}$ Sobre el poema, puede verse Bloom (2002: 78-84).

${ }^{111}$ En el libro El otro, el mismo (OC., II, p. 275).
} 
(know not me) en su riqueza y complejidad. El sedentarismo le asfixia y el héroe siente que no puede descansar de sus viajes; por el contrario, está dispuesto a seguir apurando la vida. Piensa que es persona para sufrir y gozar a lo grande, solo o con quienes le aman, y ansía seguir viendo y conociendo - como dirá Cavafis en su famoso poemaciudades de hombres, costumbres y climas; consejos y gobiernos; y lo más importante: a sí mismo, pues él mismo es una parte de todo aquello con que se ha encontrado ( $\mathrm{am}$ a part of all that I have met). Con estos monosilábicos versos Tennyson expresa el convencimiento de Ulises de que él mismo no es sino «una parte de su propia historia». Como todo ha de acabar con la muerte (Death closes all), Ulises quiere seguir ahora sólo los derroteros de su propio deseo, y cae en la cuenta de que todo lo vivido es un arco, por dondel brilla el mundo no visto, cuyo límite siemprel más y más se disipa. Y comprende también que antes del fin pueden labrarse aún trabajos de gran fama, / nada impropios de quienes lucharon con los dioses. Anhela por ello ir en pos del saber, lucero que declina, / más allá de los límites del pensamiento humano. Repara Unamuno así mismo en el verso en que proclama: no es demasiado tarde para buscar un mundo más nuevo (Is not too late to seek a newer world), y llevando el agua a su molino, confía en una España más nueva donde - como el protagonista del poema- pueda navegar allende el ocaso y los baños/ de las estrellas del poniente, hasta la muerte. Por último, comparte con el también agónico Ulises aquello que le constituye: «Un temple igual de heroicos corazones, debilitado por el tiempo y el hado, pero de fuerte ánimo para aspirar, buscar, hallar y no ceder» (To strive, to seek, to find, and not to yield). Quiere, como Ulises, encontrar a Aquiles y a D. Quijote en «el reino de la Quimera» ${ }^{112}$. Y es entonces — sigue Unamuno - cuando más quiere escribir, «escribir hojas volanderas que el viento se lleva arremolinadas a que se pudran al pie de un arbolito cualquiera y le formen mantillo». Por ello dice: «iId, pues, hojas dispersas [...] y que el viento de Dios os lleve a donde quiera!», para concluir con una vuelta a la evocación homérica de las generaciones las hojas de los árboles y las de los hombres:

¡Quién sabe si iréis a un tronco pelado y en él formaréis follaje que cante a las brisas de la eterna primavera! ¡Quién sabe qué tierna planta abrigaréis hechas mantillo

Y concluye:

¡Adelante, pues, y proa al infinito! ¡A ver dónde no se pone el sol!... [porque] el eterno ocaso es una eterna aurora.

Veíamos más arriba que para Unamuno la seducción de las sirenas homéricas radicaba en el deseo de saber que ofrecían a través de su canto. Sin embargo, una alusión de Unamuno al «Reino de la Quimera», entendido este espacio legendario por el nombre por sus moradores, seres mitológicos dotados de un simbolismo común al

${ }^{112}$ C. n. ${ }^{\circ} 1063$ (OP., III, p. 1242) 
de las nubes, invitan a detenernos un poco más en estos versos: Las quimeras de las nubes/ cuando subes/te engañan con su cantar/Ojo! son adivinajas/cuando bajas/ te desgarra su aullar ${ }^{113}$. En el primer verso existe la variante «sirenas», y como tal, pueden simbolizar perfectamente «el hechizo y la seducción del canto» trampa mortal a la postre para los mortales. En efecto, Circe advierte a Ulises del embelesamiento que padecen los hombres que escuchan la voz ( $\varphi \theta$ ópyov) de las sirenas con su «sonoro

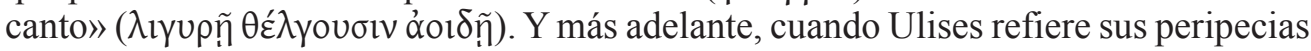

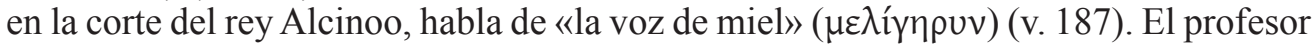
de Manuel Rabanal ${ }^{114}$ acierta al notar la estrecha relación que encierran las palabras griegas para decir: 'contar' y 'cantar', y señala de manera certera que las palabras que cuentan (relatos) conllevan también la sensualidad musical de las que cantan. El 'contar' de Unamuno no es ajeno ni mucho menos - incluso de manera inconsciente - al 'cantar' que lleva implícito. Así lo ha visto muy certeramente Rafael Sánchez Ferlosio en su libro Vendrán más años malos y nos harán más ciegos ${ }^{115}$, cuando al comentar un verso de Unamuno referido a las aguas de unos ríos - lígrimos, lánguidos, íntimosdestaca la «dactílica hiperritmia de los tres adjetivos esdrújulos» que a su parecer expresan, en contra de la austeridad y gravedad que siempre se ha atribuido a su autor, el «secreto ardor de una sensualidad capaz de conservar su más aguda receptividad, aun embozada tras la ascesis de una hirsuta conciencia puritana». Y concluye:

Es el esquinado y esquinoso don Miguel de Unamuno quien nos da, así, la más genuina muestra de cómo la ascesis, la renuncia pueden celar una incondicional fidelidad a la carne, a la felicidad ausente y añorada a interdicto de conciencia por la visión de un mundo flagelado por la muerte y el dolor (...) El desabrido catedrático deja escapar entre sus tantas veces broncos, tropezosos y preceptivos versos el secreto de un intacto hedonismo adolescente.

Siguiendo esta senda podemos acabar con los versos de su poema Mediterránea ${ }^{116}$ —ahora del Unamuno contemplativo - inspirados en el mundo helénico (e hispano) envueltos sensualmente en ritmo dactílico:

Olivos, higueras, cipreses marmóreos montes pelados regatos sin fondo que rompen al sol y a la luna los rayos.

La abeja recoge la crema de la flor del hueso del campo, Platón alecciona a las ranas en el mediterráneo charco.

\footnotetext{
${ }^{113}$ C. n. ${ }^{\circ} 1063$ (OP., III, 498).

${ }^{114}$ De Rabanal (1972: 151, n. 33).

${ }^{115}$ Sánchez Ferlosio (1993: 35-36).

${ }^{116}$ C. (OP., III, p. 272).
} 
Las velas latinas recogen

arrebol teñido de ocaso

cigarras de sol embriagadas

a Apolo desgranan sus cantos.

Nítidos, férvidos crepúsculos

que paren estrellas soñando,

la noche cobija a los dioses

naúfragos en remoto oceano.

De manera contradictoria, Miguel de Unamuno seguirá volviendo (como Ulises a Ítaca) hasta el final de sus días al padre de la poesía europea a pesar de su condena del «estéril esteticismo», y siempre de manera ambivalente. De todo lo anterior quizá quede clara una idea: A partir del tratamiento que del mundo homérico hace D. Miguel, pueden vislumbrarse dos Unamunos, ambos reales, distintos e incluso contradictorios.

\section{OBRAS COMPLETAS DE UNAMUNO}

Miguel de Unamuno, Obras completas, Ed. Manuel García Blanco, OC. IX vols. Madrid 19661971.

— Poesías completas, Ed. Ana Suárez Miramón, OP. IV vols. Madrid 1987-89.

\section{Abreviaturas}

CEA, Contra esto y aquello

AVE, Andanzas y visiones españolas, 1922.

P. Poesías, 1907.

PG. Paz en la guerra, 1897.

PS. Poesías sueltas

PTPE, Por tierras de Portugal y de España, 1911.

$R D$, Romancero del destierro, 1928.

RSL. Rosario de sonetos líricos, 1911

RNM. Recuerdos de niñez y mocedad. 1908.

ETC. En torno al Casticismo, 1902.

DI. Diario íntimo, 1897.

VDQS, Vida de D. Quijote y Sancho, 1905.

ST, Del sentimiento trágico de la vida, 1912.

EE, Ensayos erráticos o a lo que salga, 1901-1924.

$D E A$, De esto y aquello. 


\section{BiBLIOGRAFÍA}

Alsina, J. (1957), «La Helena y la palinodia de Estesícoro», Est. Clás. 4, 22.

Bettini, M., y Brillante, C. (2008), El mito de Helena, trad. F. Díez Plata.

Bloom, H. (2002), Cómo leer y por qué. Barcelona.

Borges, J. L. (1996), Obras completas, 4 vol., Barcelona

BRINK, A. (1993), La primera vida de Adamastor, trad. J. J. del Solar.

Camus, A. (1951), El mito de Sísifo. Trad. L. Echávarri, Madrid 1985.

- El verano. Bodas. Trad. A. L. Bixio, Barcelona 1979.

De AzúA, F. (1988), Lecturas compulsivas, Barcelona.

De Cuenca, L. A. «La Helena de Eurípides y un poema de Giorgos Seferis», Est. Clás. 78 (1976), 371-378.

De Rabanal, M. (1972), «El atractivo de las sirenas», en Grecia viva, Madrid, pp. 139-153.

— «La Helena de Eurípides», Est. Clás. 65 (1972), 57-65.

García Gual, C. (2014), Sirenas. Seducciones y metamorfosis, Madrid.

Gómez Carrillo, E (1908), Grecia, prólogo de J. Moréas, Madrid.

González Serrano, P. «La pradera de los asfódelos», en Más cerca de Grecia 16-17 (20002001) 105-120.

Grimal, P. (1951), Diccionario de Mitología griega y romana.

JuARIsti, J. (2012), Miguel de Unamuno, Madrid.

López FÉrez, J. A. (ed.) (1994), La épica griega y su influencia en la literatura española, Madrid.

- (coor.) (2010), Mitos clásicos en la literatura española e hispanoamericana del siglo XX, Madrid.

Machado, A., Poesía y Prosa (OC., ed. O. Macrí), 4 vol., Madrid 1989.

Marlowe, Ch. La trágica historia de la vida y muerte del doctor Fausto, intr.y trad. J. C. Santoyo y J. M. Santamaría, Madrid 1984.

Martínez Conesa, J. A. (1998), «Remembranzas clásicas en D. Miguel Unamuno», en Corolla Complutensis. In memoriam Josephi S. Lasso de la Vega Contexta, Madrid, pp. 755-762.

Melero, A., «El mito clásico en D. Miguel de Unamuno», en J. A. López Férez (coor).

Rodríguez Alfageme, M. I. «Mitos en Antonio Machado», en J. A. López Férez (coor.), 97-112.

- (2011), Mnemosyne: disfraz y noticia. Trazas de la tradición clásica en La literatura española desde los orígenes al siglo Xx, Valencia, pp. 239-318.

Ruiz de Elvira, A., «Helena, mito y epopeya», CFC. 6 (1974), 95-134.

SÁnchez Ferlosio, R. (1993), Vendrán más años malos y nos harán más ciegos. Barcelona.

Seferis, Y., Poesía completa. Trad. P. Bádenas, Madrid 1989.

Tovar, A. (1966), Aspectos de la Helena de Eurípides, en Estudios sobre la tragedia griega, Cuadernos de la Fundación Pastor, 13, Madrid.

Velasco López, M. ${ }^{a}$ Henar (2000), El paisaje del más allá, Tesis, Valladolid. 